\title{
The Extent of Al-Qaeda's Presence in Africa: Security Threats and Policy Implications to the U.S.
}

\author{
Daniel Chigudu ${ }^{1 \mathrm{~A}}$ \\ A University of South Africa, South Africa
}

Received: February 14, 2021 | Revised: April 13, 2021 | Accepted: April 30, 2021

DOI: $10.33445 /$ sds.2021.11.2.4

\begin{abstract}
Following a period close to fifteen years of fighting the extremist terrorist group Al Qaeda in Pakistan and Afghanistan, the United States (US) is faced with diverse security threats from affiliates of Al Qaeda in Africa. This study explores the extent of Al Qaeda's presence in Africa, security threat and policy implications to the US. A qualitative methodology through document analysis and informed by the interpretive research paradigm was employed. With Al Qaeda's continued growth, there could be nuclear terrorism, arms and drug trafficking among other threats. Policy recommendations are given for the United States of America.
\end{abstract}

Key words: terrorism, Al-Qaeda, threat, US, Africa.

\section{Introduction}

Efforts to counter terrorism were noticeable more in the US- Africa policy when the Islamic Court Movement seized power in 2006 from Somalia (Lyman,2017). This led to the incursion of Somalia by Ethiopia which had US veiled backing and even the fighting that is currently engulfing the already ruined country. Primarily, in 2007 Pentagon pronounced an intention to set up a new and integrated Africa Command (AFRICOM) bringing various programmes in Africa together, a move calculated by US to focus on security issues on the continent. The concern by US was understandable ostensibly because Africa is less invulnerable to terrorism threats than any one other landmass. The blend of comparatively weak states, religious and ethnic diversity, poverty, and ungoverned space in many cases all expose Africa to the vagaries of terrorism. Many of these target African regimes, for instance, the radical Taliban and Islamic Maitatsine in Nigeria, or the self-styled Christian Lord's Resistance Army of Northern Uganda. Others lucidly pursue an agenda which is international in nature like the Al-Qaeda in the East coastal areas of Africa and seemingly
Sudanese and North Africans who are back home after schooling and participating in Iraq's uprising.

Lyman (2017) contends that, challenges are now looming in the reactions by the US and Africa to terrorism. Critics are worried that the Africa Command establishment together with the US counter-terrorism initiatives are a precursor to an intensification of a US policy of militarisation in the continent. The contention by these critics is that, it is only the eradication of root causes of violence and terrorism such as poverty, discrimination, despotism, weak states, and related conditions, that will be able to fight such threats effectively. They argue that a thrust on security alone encourages practices of authoritarianism hence undermining Africa's efforts bent on improving democratic governance.

However, the current terrorism in the African landscape is ghastly (Meservey,2019). In the Sahel region, the Islamist terrorists have multiplied operating at a high level. Meservey observes that, in the Sahel region, only Al-Qaeda in the Islamic Maghreb was traditionally active

\footnotetext{
${ }^{1}$ Corresponding author: Academic Researcher College of Economic Management Sciences University of South Africa, e-mail: danchigudu@gmail.com
} 
but at least ten groups of Islamist terrorist are now operating there while Al-Qaeda and ISIS remain a threat in North Africa. Al-Shabab in the North of Mozambique, a terrorist group different from Al-Shabaab in Somalia, is so deadly recently driving away mercenaries from Russia. The relatively counter terrorism success stories in Africa are reflecting signs of a bleak future as the African people continue to feel a sense of injustice and marginalisation (Meservey,2019). This is the pillar and post of Africa's phenomenon of terrorist to which the US can help to address while Africa itself takes lead the way.

The AFRICOM was initiated to deal mainly with the security threat from Al-Qaeda in the Islamic Maghreb (AQIM) which is evidently AlQaeda's affiliate, although the mandate had to be extended to include other ISIS and al-Qaeda affiliated organisations. The General and AFRICOM's commander to the Senate Armed Services Committee known as Waldhauser recognised violent extremist organizations (VEOs), terrorist groups affiliated to Al Qaeda and ISIS (AFRICOM, 2018, online) as being the "greatest threat" to the US in Africa. While the AFRICOM supports the Somali President, who was elected democratically it remains unclear why the Trump administration has continuously concentrated on Somalia. Besides the continuity from the administrations with respect to the combat against Al-Shabaab and affiliates of $\mathrm{Al}$ Qaeda, one reason for the military's continued efforts in Somalia could be the US interests for Somalia's location to one of the world's main shipping lanes. This could explain why Obama had vested interests in Somalia's problem of piracy. Also, Somalia is closely located to Yemen which is currently involved in the civil war to which an Al Qaeda affiliate is actively involved.

The US security policymakers and practitioners have of late been worried increasingly about Al Qaeda's potential to become influential in the highly Muslim populated and impoverished developing countries. (Forest,2011). Some projections have even indicated Al-Qaeda's significant presence in their operations, camps of training, and ideological hubs of fundamentalism all over subSaharan Africa. One US Rear Admiral Naval officer had this to say in his Congressional testimony, "Africa is an emerging haven for our enemies in the Global War on Terrorism" (Hamlin,2005) cited in Forest (2011). Moreover, Shillinger (2006) observes that Southern Africa is made up of weak states and some economic strengths, social seams, historic attitudes and links that present an opportunity and sufficient attraction for terrorism. According to Hamlin, the degree of terrorists' presence in South Africa was not clear. However, terrorist group's inactivity in Nigeria and South Africa, Africa's largely Muslim populated areas remains a matter of concern.

The Islamic State's rise and the rapidity with which it has expanded into territories across Iraq and Syria has sometimes taken the limelight away from Al Qaeda. But the US has continued to warn that Al Qaeda is determined to attack her, predicated on setbacks experienced by the Islamic State Syria and Iraq.

\section{Background}

The declaration that on the 4th of October 2017 four soldiers from the US were killed during combat in Niger was a confirmation that indeed the US military was actively participating in Africa's war on terrorism (Searcey, Cooper \& Schmitt, 2017). The surprise attack was made between Niger and Mali in a distant border part, where the Third Special Forces Group (TSFG) was on patrol together with some forces from Nigeria. This came about when these forces had gone after an Islamic State in Iraq and Syria (ISIS) leader believed to have been in the neighbourhood. The US soldiers got attacked as they returned from a village located some distance away from their station although hardly after two hours the French air force was there to assist (Callimachi, Cooper, Schmitt, Binder \& Gibbons-Neff, 2018). It is not known as to who tasked the TSFG to target ISIS given that, US President Trump declined on the 25th of October 2017 that he sanctioned the attack, except giving an authority to win a war 
(Callimachi, et al, 2018). In his remarks, the US President claimed credit for having won the war in the Middle East in eight months which the previous administration could not do, and that even if they go to some places or even Africa they will be met there (Trump, 2017).

The statement by Trump brings to light that, combatting ISIS in Africa is an extension of the Middle East battle against its enemies (Al-Qaeda included) which have gone back into their safe havens. The wars against ISIS and AI Qaeda will continue as part of the war against terrorism by the US, taken over from the Bush and Obama administrations (Griffin,2018). This could be seen as a significant US approach ever since the war in Kosovo around 1999, when European and US deaths during interventions battles overseas were almost intolerable. Apart from this, beyond Trump's election into office the African continent could have never been the US strategic priority (Kandel, 2016). On the other hand, after the 1998 attack of the US Embassy in Tanzania and Kenya by Al Qaeda and the 11 September attacks, US began taking cognisance of terrorism security issues in Africa (Kandel, 2014). Griffin (2018) notes that, even though Africa is not under the same security lens as Iraq and Afghanistan, the US has since started to take more action against groups of terrorists in the continent militarily.

The 2007 establishment of AFRICOM and its successive activities against ISIS and Al Qaeda groups fit neatly into this rationality. Griffin (2018) argues that before Trump's election into power, military action by America only represented part of the global US- Africa policy which include economic interests, development and humanitarian aid. In 2012, the US developed programs for poverty reduction, improving health, helping youths and women, promoting sustained food security and to work on climate change (White-House, 2012).Before the AFRICOM was founded military affairs were embedded in the European Command which was seized with responsibilities for the Madagascar, Indian Ocean in the Pacific Command and North Africa in Central Command
(Bush,2007). Emphasis was given to this specific command that, it had no centre of operations in Africa, but would remain in the European Command headquarters situated in Stuttgart, Germany. It is noted that, the creation of AFRICOM's was perhaps coincidental with Al Qaeda's expansionary operations into Africa after the wars in Iraq and Afghanistan. According to Stenersen (2017), the 1998 original Al Qaeda's charter was very clear that, this group was poised to be a jihad movements' gathering point worldwide.

Byman (2010) observes that some research of the Al Qaeda phenomenon often use business terminologies to explain the advent of new groups related to Al Qaeda hence they talk about mergers, branding and acquisitions. Ahead of Al Qaeda merely as a name, it has frequently funded the groups affiliated to it (Byman, 2010). In Africa, Al Qaeda in the Islamic Maghreb (AQIM) originally created from terrorist groups that participated in Algeria's civil wars of the 1990s was first to join Al Qaeda in 2006 (Thomas,2018). The AQIM group was a beneficiary of the demise of Libya's Muammar Qaddafi in 2011 as well as from the influx of fighters and weapons into Niger and Mali. This however presents AQIM as a structure which is not monolithic but one composed of different groups, some of which are not keen to be allies of the main Al Qaeda group (Memier, 2017). The Ansar al-Sharia a group created after the fall of Qaddafi in Libya got affiliated to Al Qaeda up until 2017 when it got disjointed as some of its members opted out to join ISIS. In Somalia, an insurgent and local group, Al Shabaab, became an affiliate of Al-Qaeda in 2012, since these two had earlier collaborated back in 2008 to contest the intervention in Somalia by Ethiopia (Agbiboa, 2014). Although in Nigeria, Boko Haram's affiliation is not well known some of its documents found following bin Laden's death reveal close ties with AQIM after 2009 (Joscelyn, 2017; Griffin,2018).

According to Krech (2011) the familiar AQIM sub-groups are, for example, Al- Qaeda in Sudan, Al-Qaeda in Morocco and Al-Qaeda in 
Mauritania with operational areas comprising the entire Sahel and Sahara regions; Tunisia, Algeria, Libya, Burkina Faso, Morocco, Mali, Niger, Mauritania, Niger, Sudan and Nigeria. This area operated by Al Qaeda is a lot bigger than Europe although with a small contingent of fighters. The AQIM's strength has been projected at almost 800 fighters, grouped into teams of close to 25 combatants each. The teams' operating areas are assigned numbers and then designated to particular taskforces. AQIM has been able to finance itself by taking both foreign and local captives (Krech, 2011). AQIM reportedly extorted 10 million euros as payment for some captives from Spain in 2010 (Al-Hayat, 2010). AQIM's main source of funding is the trading of cocaine which is taken from West Africa before being trafficked into the European Union (EU). The Algerian government reports that AQIM is believed to have made a profit of nearly 50 million euros all from trading drugs in the period 2007-2011 (Krech, 2011).

With most of the AQIM fighters working explicitly for drug cartels of Columbia, this portrays the group according to Krech (2011), as a central global mafia for cocaine and on the other side a 50 per cent terrorist group. Just like the Al Qaeda groups in Pakistan and Afghanistan that are strongly linked to the mafia of heroin, it is believed that in the long run, AQIM could subsist as a network of drug cartels' if Al-Qaeda collapses. Perhaps it is this reality that exceedingly holds back the war against AQIM. During arsenal plundering in Libya, lots of man portable air defence systems (MANPADS) whose types included Strela-2 and Strela-2M projectiles could not be found. The Qaddafi regime is believed to have been in possession of almost 20,000 Strela MANPADS Russian-made which have found their way into AQIM armouries. However, these MANPADS are older models with a manufacturer guaranteed effective lifespan of ten years (Krech, 2011). Furthermore, Schroeder (2011) observes that, the ability to use Strela MANPADS requires extensive and exhaustive training. In view of these possessions, the US Secret Service gave notices to all the oil companies and US embassies in the Sahel and Sahara regions of likely civilian airliners attack by AQIM using MANPADS. AQIM has supporters and followers dotted outside Africa in countries such as Spain, Germany and France, this explains why the risk of attacks related to the group in the EU is quite high. The Eiffel Tower in Paris was vacated in 2010 alone three times, as a result of potential threats of an attack by AQIM (Krech,2011).

As far back as 2008, the US Director of National Intelligence, Michael McConnell, advised the Senate Select Committee on Intelligence that, there was a security threat to the US from the "ongoing efforts of nationstates and terrorists to develop or acquire dangerous weapons and delivery systems" (McConnell,2008, online). In addition, Saenz (n.d) asserts that research should be done in North Africa to evaluate the current flourishing of Al Qaeda's affiliates after the uprising during the Arab Spring and the increased insecurity in a rapidly changing environment. Al Qaeda has revealed some interests in acquiring a weapon of mass destruction (WMD) and materials that are proscribed. Even though the chance for terrorist groups to obtain nuclear weapons is low, if they do, the consequences could be cataclysmic. As AQIM Al and Al-Shabaab steadily grow, they have a potential threat of nuclear terrorism. The North Africa and Middle East exhibit a 'next generation' of increased challenges facing the US (Jeanne, 2013).

It is critical that the possibility for trafficking proscribed materials in localities like Africa with high insecurity and with groups interested in procuring them should be studied. It is also important to determine how strong such an intent is presently being pursued, and if they are nearer to getting nuclear materials owing to chronic civil unrests, levels of conflict and technological growth.

\section{Compelling case}

It has been reported recently that some AlQaeda affiliated groups and the ISIS fighting one another in the Middle East, are in fact closely working together in Africa to wrest power in 
territories particularly throughout West Africa (Paquette \& Warrick, 2020). This has sparked fears that, the threat to the region could develop to a global crisis if no counter measures are urgently taken. The fighters seem to be organising attacks and mutually carving out influential areas that are agreed upon. The report quotes the Head of the US military's Special Operations arm in Africa as saying:

"What we've seen is not just random acts of violence under a terrorist banner but a deliberate campaign that is trying to bring these various groups under a common cause. That larger effort then poses a threat to the United States" (Paquette \& Warrick, 2020, online).

Increasingly, in the recent few months the militant group has employed tactics which are sophisticated, deep-rooted into Burkina Faso, Niger and Mali, army bases have been ambushed, with villages dominated by shocking amounts of force. No areas have been declared caliphates as a ploy to evade study from the West, buy time for training, gather momentum and scheme attacks that could eventually extend to the international major targets. A grouping of Al Qaeda stalwarts known as the Jama'at Nasr al-Islam wal Muslimin (JNIM) is believed to be having about 2000 armed forces in West Africa only. Despite being foes in Yemen and Syria, both ISIS and Al Qaeda have a more fluid adherence to West Africa strengthened by practical trepidations and tribal relations ahead of ideological orientations. There common enemies include the local administrations to which they want to subdue and the West. The
US long expressed some worries over the likelihood of an unholy alliance between the most infamous terrorist groups in the world (Paquette \& Warrick, 2020). These worries and concerns have increased significantly after the downfall of the self-proclaimed caliphate in Syria and Iraq by ISIS. According to Paquette and Warrick (2020, online) citing a high-ranked official from the French military, the radical groups are "more organised and they're more mobile, they're carrying out professional attacks like we've never seen."

Back in 2011, Krech (2011) asserted that, in Africa not less than 20,000 combatants were readily fighting in the corner of $\mathrm{Al}$-Qaeda and that they were increasingly becoming strategically connected. A lot more operations by Al-Qaeda take place in sub-Saharan Africa, for instance, in Uganda and Tanzania among others. Adesoji (2010) argues that Boko Haram could become an affiliate of Al-Qaeda as well. The influence of Al-Qaeda in Africa is growing with its activities in the period 2009- 2011 well pronounced in 19 African countries (Krech,2011). This figure could have since risen as more coalitions with sub regional groups increase. Al Qaeda is presumed to have three strong members comprising part of its level of strategic command all originating from the African continent. It remains unclear why the Arab Spring has not injured Al-Qaeda. This study examines and highlights the extent of Al Qaeda's threat to security in Africa to date and how this influences the US policy on the continent.

\section{Literature Review}

The literature review focuses on, the origins and presence of Al Qaeda in Africa, Al Qaeda in East Africa, Southern, Central and West Africa, weapons of mass destruction (WMD) and Al Qaeda's interests.

\section{The origins and presence of Al Qaeda in Africa}

In the beginning, the presence of Al-Qaeda has been known predominantly in countries of East and North Africa. With respect to the global jihad, the role of North Africa is linked intimately to Al-Qaeda's establishment. When the Soviet Union forces exited Afghanistan in 1989, a lot of people from North Africa went back to their countries with a sense of pride after fighting side-by-side with the Afghan mujahideen. They felt they had succeeded in their jihad against a global force which had raided a country with a Muslim belief. They went back to Egypt, Morocco, Algeria, Tunisia and Libya their home 
countries, where most of them had to join the extremist Islamist groups in the locality. The North African returnees whose number was the largest, were fighters of the Algerian origin and descent. On arrival back home they quickly identified themselves with a burgeoning movement of Islamists which expressly provided an institution for their sentiments as self-styled holy fighters (Forest,2011).

At the time Algeria held its first parliamentary elections in December 1991, the biggest Islamic opposition party, the Islamic Salvation Front (ISF) looked as if it was triumphant. The Algerian militant government reacted by annulling the results of the election. This triggered the founding of an organisation, the Armed Islamic Group (GIA), which as expected appealed to these former Afghan war fighters trained by $\mathrm{Al}$ Qaeda. In the meantime, a well-known war veteran in the Afghan conflict called Abdul Azzam had started to establish centres of training in Afghanistan in order to bolster the growth of a mujahideen international group. This could assist Abdul Azzam to set free the territories of Palestine, his home, from occupation by Israel. In this attempt, he got assistance from a young and wealthy Saudi known as Osama bin Laden, with whom Abdul Azzam established in 1988 Al-Qaeda (the Base). Some members of the GIA had to travel to Afghanistan where they participated in guerrilla warfare, advanced training and also forged longterm ties with others from a network of jihadist growth (Nasiri, 2006; Wright, 2006; Bergen, 2002; Burke,2004).

The GIA waged a vicious civilian annihilations campaign in the period 1992-1998, often destroying all villages around its operational area. In 1998, these increased attacks on civilians generated an off-shoot, popularly known as GSPC (Groupe Salafiste pour la Prédication et le Combat) or the Salafist Group for Preaching and Combat. Therefore, the leadership of the GSPC was largely composed of members of former GIA and Al-Qaeda-trained. This leadership carved in inventive tactics and global ties to this embittered fight against the regime. The GSPC had the audacity to take hostage of 32 tourists from Europe in 2003, holding them for many months up until a ransom was reportedly paid by German to the tune of five million euros Kennedy-Boudali, (2007) as cited in Forest (2011). When the hostages were released, there were running battles through Mali up to Chad where the GSPC cell leader Amari Saifi was later captured with the help of the US (Forest,2011).

Some other cells of the GSPC received mujahideen training so as to get into Iraq's battlefield, and accompanied representatives from Al-Qaeda into North Africa intending to unify the different local groups of terrorists under the banner of Al-Qaeda (Ulph, 2003). The Moroccan forces disrupted a plot by Al-Qaeda in 2004 meant to ambush European and American ships sailing through the Gibraltar Strait. It is in the same year when GSPC declared openly its loyalty to Al-Qaeda (Daly,2005). As noted by Forest (2011) the GSPC cells have long been found in France, the Netherlands, Italy, Spain, Canada, the United Kingdom and Germany. In North Africa some groups like the Moroccan Islamic Combat Group and the Libyan Islamic Fighting Group are connected to the jihad AlQaeda's global system. Broadly, North Africa has been liable for the attacks in Tunis, Madrid, Casablanca and Algiers. Some North Africans have also been arrested for participating in terrorist foiled plots in London, Barcelona, Montreal and Vancouver.

The GSPC rechristened itself in January 2007 and became known as the Organization of AlQaeda in the Lands of the Islamic Maghreb (AQIM). Since then, it has been accountable to many violent terrorist incidents across the region, as well as the car bomb attack in December 2007 at the UN office in Algiers. This attack claimed 17 lives. According to Forester (2011), AQIM has also been responsible for the attack in June 2008 on French contractors; in June 2009, the death in Mauritania of an American; in July 2009, the murder of 11 Algerian forces; and several abductions of foreign nationals held for ransom. According to Kennedy-Boudali (2009) in North Africa, most of the attacks by AQIM range from ambushes, abductions, roadblocks, bombings and extortions. Operating from a base situated in 
Northern Mali, AQIM made several kidnappings of tourists and foreign aid employees all over the boundary region of Algeria, Mali, Niger and Mauritania (Baldauf,2009). Back in 2010 on the $10^{\text {th }}$ of March, the group made public a video of Abu Yusuf AQIM leader with a warning against uniting with the West and the US in their quest to fight against Al Qaeda (al-Shishani, 2010). This group presents a security threat to North Africa in particular and the region in general. There are some indications showing that its authority is extending to some nations in the South-West of the Sahara Desert too (Forest, 2011).

To the Eastern part of Africa, it is well known that in the early 1990s Osama bin Laden together with his associates stayed in Sudan (GPO,2004). Osama bin Laden was invited by Hassan al Turabi the leader of National Islamic Front (part of a grouping which usurped power in Khartoum). The invitation was for bin Laden to assist in a war versus the African Christian separationists in Southern Sudan. Also, to assist in road construction, to make use of Sudan as a command centre for global operations and to prepare for a worldwide jihad. In 1991, Bin Laden travelled to Sudan where he established a huge and intricate set of entwined terrorist businesses. These would comprise several enterprises, bank accounts of a global network and non-governmental organisations. In order to fulfil his deal as invited, bin Laden made use of his company to construct a new road starting from the capital Khartoum right down to Port Sudan on the coast of the Red Sea. In the interim, the finance personnel of Al-Qaeda and top officials took advantage of their positions in bin Laden's business entities to procure technical equipment, explosives and weapons for purposes of terrorist activities (GPO, 2004).

Osama bin Laden founded the Islamic Army Shura during this period meant to operate as the body for coordinating the association of terrorist groups. The Islamic Army Shura encompassed his own Al-Qaeda Shura and representatives of some terrorist groups that were operating independently at that time (GPO,2004). While this Islamic army was at its formative stage, bin Laden accepted groups from South-East Asia, the Middle East and countries from Africa such as Uganda, Libya, Morocco, Tunisia, Eritrea, Somalia, Mali, Chad, Nigeria and Niger. Bin Laden seems to have loved staying in Sudan till he succumbed to pressure from the international community, this was spearheaded by both regional and Western countries particularly after an attempt to assassinate the Egyptian President Hosni Mubarak in June 1995 while in Ethiopia. This assassination attempt was associated with Al-Qaeda hence led the authorities in Sudan to persuade him to go. On May 19, 1996, He moved to Afghanistan on the $19^{\text {th }}$ of May in 1996 where he got Taliban security. It was in August that year, where bin Laden released his initial fatwa, a statement declaring war against the US (GPO,2004). What happened after the declaration is well-known. In 2006, Sheikh Abu Ya'li led a terrorist group called Al Qaeda Organisation in Sudan and Africa, declared that it was responsible for executing the chief editor of the Sudanese daily al-Wifaz in September, and also Muhammad Taha, who republished an article on internet that doubted the parentage of Prophet Muhammad (Rabasa, 2009). However, since 2001 the influence of Al-Qaeda in in Sudan seems to have significantly declined.

\section{Al Qaeda in East Africa}

According to Forest (2011), for many years the Coast of Africa's Swahili witnessed the Muslim presence significantly, and yet hardly ever demonstrated tendencies of radicalism. At the time when bin Laden stayed in Sudan, he sent some operatives to Kenya who did set up an NGO for disguise. According to GPO (2004) in 1992, Abu Ubayda al-Banshiri who at that time was a commander for Al-Qaeda's military created a cell in Kenya (FBI,2011). The primary purpose of the cell was to support and supply arms to the Islamic combatants in Somalia, instead of radicalising members of the local community or operating against the administration of Kenya seen as pro- Western (GPO,2004). However, members of the cell had instruction to distinguish appropriate Western targets resident in Kenya for possible ambush. According to GPO (2004), Ali Muhammad made surveillance in Nairobi on the USAID building, US embassy, French Cultural Centre, the French 
embassy, the Israeli and British targets. After being arrested and trial in court, Muhammad pleaded guilty to five conspiracy counts to kill US nationals, kidnap or destroy the US property.

As bin Laden made a second fatwa, in February 1998 now directing all Muslims in the world to execute where possible American nationals and their supporters, the plot in East Africa by Al-Qaeda to hit two US embassies had been finalised. Almost concurrently, on the $7^{\text {th }}$ of August 1998, two trucks laden with bombs drove to Nairobi and Dar es Salaam targeting the US embassies. In Nairobi 213 people including 12 Americans were killed and in Dar es Salaam, 11 people died with over 5,000 sustaining injuries according to Vadlamudi (2007) as cited in Forest (2011). The attacks were scheduled to take place from 10:30 am to 11:00 am, when Muslim believers would be holding prayers. It is important to note that, these attacks were planned to take place eight years to the day following the landing of the US forces in Saudi Arabia in a reaction to Saddam Hussein's Kuwait invasion in 1990 (Vadlamudi, 2007 in Forest, 2011). On the $28^{\text {th }}$ of November, 2002, another attack associated with Al Qaeda occurred in Kenya (CTC Report, n.d).

For decades, going up the East African coast, Somalia has been one amongst the very active political violence hotspots on the African continent. Since the early 1980s, radical Islam has been present in Somalia largely as Al-Ittihad al-Islami (AIAI), which is a group created through a combination of various Salafi Islamic terrorist groups that were opposed to Siad Barre's dictatorship. In the 1990s after Barre's administration collapsed, the AIAI garnered support partly by proffering social services and employment essentially filling a gap made by the paucity of a well performing government. All at once, AIAl became responsible for various attacks on civilians and government targets. Due to the group's growth and increased violence and desire to bring political change, in December 2001, the US added the AIAI to the list of foreign terrorists organisations.

However, regardless of Al-Qaeda's substantial operations in Kenya, Sudan and Tanzania, it was not able to set up a presence which is solid in Somalia in the mid-1990s. Efforts by Al-Qaeda to institute its presence South of Somalia and set a base for attacking the Western targets somewhere else were futile. In Somalia, the jihadists were not able to gain traction in the early 1990s because the group underestimated significantly the costs associated with activities in a failed state as its members were seen as aliens. In the 1993 Black Hawk Down, a Mogadishu incident, Al-Qaeda declared having been involved in it whereby the gangs of Somali warlord Mohammad Aideed gunned down a US military helicopter. The bodies of the forces were subsequently pulled through the streets. But there is no sufficient evidence to support the claims. Forest (2011) asserts that, it is only recently when Al-Qaeda has made its presence in Somalia stronger. The Somali militant group Al-Shabaab (The Youths) the Somali terrorist group declared in January 2010 its allegiance to Al Qaeda and Osama bin Laden (Wassef 2009 cited in Forest,2011).

\section{Southern, Central and West Africa}

In comparison with East Africa and North Africa, Al-Qaeda's influence and presence across the remainder of Africa is limited. Without a doubt, some areas of Islamist extremism do exist and are a worry to security specialists, but they are not as common and unique instances, with little ties known of them to the network of the global Al-Qaeda (Forest, 2011). For instance, in North of Nigeria there exists Boko Haram a term used in Hausa meaning Western education is not acceptable. The group propagates the supremacy of the Muslim culture and it seeks to impose the austere Islamic law. Boko Haram has bombed police stations in Nigeria, maimed and executed hundreds, decimated infrastructure and fought government security forces throughout five Nigerian's states. The group hit the media headlines in August 2009 when it ransacked churches and police bases close to Maiduguri a town which is the hub of Borno state, igniting an upsurge of violence. This attracted attention from the public which had to focus on the Boko Haram's grievances, including the heavy-handed response by the local security forces which claimed the extra-judicial execution of Mohammed Yusuf the group's 
founding leader among others (Schwartz, 2010).The Al-Qaeda's leader in the Islamic Maghreb pledged to give assistance to Boko Haram in May 2010 in terms of training and weaponry. That year in October, in response to the offer, Boko Haram's senior member allegedly pledged adherence to Al-Qaeda (AMM, 2010). However, thereafter in the same year it appears there is no indication to confirm any formal ties made (Forest, 2011).

In general, apart from the exceptional striking incident that occurred in December 2009 of Umar Farouk Abdulmutallab nicknamed by the media fraternity as 'underwear bomber' there has been no signal of Al Qaeda's potential influence or growth in Nigeria. In another part of West Africa, AQIM members were netted during a covert operation for drugs in Ghana around December 2009. Evidence adduced to the court of law reveal that some elements from the US Drug Enforcement Agency penetrated the AQIM cell masquerading as Colombian nationals (Barrett, 2009 cited in Forest,2011).

Down South, the cases of Al-Qaeda's threat to the sub-Saharan Africa region are scantier and sketchier. In Zambia, sometime back in July 2005, an assumed British Al-Qaeda member called Haroon Rashid Aswan was arrested. At present there is no evidence of any substantial structured presence of Al-Qaeda in Southern Africa. There are exceptions which are very minor in South Africa. In 2004, there were fears which were reported about possible attacks by terrorists in South Africa. It was when some people reportedly associated with Al-Qaeda got arrested with comprehensive geographical maps of Pretoria, Johannesburg, Durban and Cape Town (Forest, 2011). But, Holt (2004) observed that, a group of religious extremists already existed in South Africa known by the US State Department [the People Against Gangsterism and Drugs (PAGAD)] as the Foreign Terrorist Organization. The group has described itself as one which is bent on protecting the interests of ordinary South Africa's Muslims from the bane of organised crime. Even though it also habitually advocates for the anti-Western language and is a fiery critic of the US foreign policy. (Holt, 2004). According to DS (2006)
PAGAD has since been linked to many highprofile attacks of high-profile in the Cape Town, which includes the 1998 bombing of the Planet Hollywood and a myriad of bombings in the urban in 2000. To date it appears however that no evidence has been presented suggesting that indeed PAGAD has any ties with Al-Qaeda.

Forest (2011) observes that in January 2007, the US labelled two cousins of South African origin being Farhad Dockrat and Junaid Dockrat as Specially Designated Global Terrorists owing to their allegiance to the Taliban and Al-Qaeda. The two were alleged to have been bankrolling the operations of Al-Qaeda (Schanzer, 2007). AlQaeda has not yet shown any expressive inroads into South Africa.

\section{Weapons of mass destruction (WMD) and Al Qaeda's Interests}

The interest of Al Qaeda to use weapons of mass destruction (WMD) against its enemies including the US started earlier than the $11^{\text {th }}$ of September 2000 (Saenz, n.d). Osama bin Laden declared in 1998 that, procuring and making use of WMD was jihad's part of its integral agenda. Years later after the declaration, he commanded the top leadership to develop or purchase biochemical and nuclear WMD (MowattLarssen,2013). It was also reported in January 2002 that, the officials from US in Afghanistan found nuclear weapons diagrams in a house owned by Al Qaeda (Lumpkin, 2002). In one of the documents found, there was a nuclear weapon described as the superbomb with some annotation reflecting an ability to develop a nuclear blast (Boettcher \& Arnesen,2002). A deserter from Al Qaeda Jamal Ahmad al-Fadl made a startling claim that he was instrumental in the purchasing of a US\$1.5 million worth of uranium in Khartoum, Sudan. The item was covered in a cylinder whose size was approximately $2 \mathrm{ft} .-3 \mathrm{ft}$ long with an inscription 'South Africa' on it (McCloud \& Osborne, 2001). Apart from some efforts to procure nuclear materials, Al Qaeda had incidents where it was involved in the radioactive material smuggling. For instance, in 2002, Jose Padilla a criminal from Chicago connected to Al Qaeda expressed their desire to create what he termed a dirty bomb. He was instructed to get nuclear waste 
for use to soil an area after the detonation of a traditional bomb (Zaitseva \& Hand, 2003).

The interest by Al Qaeda to obtain chemical, biological, radiological, and nuclear (CBRN) and even WMD materials, has increased though at a slow pace in the past few years (Saenz, n.d). With this glaring interest, the use of CBRN materials by Al Qaeda to achieve its goals cannot be discounted. What could influence nuclear terrorism is the ease of accessibility to proscribed materials. Since the networks built by Al Qaeda on anti-Western rhetoric is basically thrust on the US, amplified interest in using the CBRN material is frightening. At present, Al Qaeda has the most sophisticated network of terrorism having the requisite financial resources, geographic reach, experience and organisational skills to vigorously pursue the nuclear terrorism agenda. The dominant affiliates of Al Qaeda in Africa should be scrutinised continuously to preclude any nuclear security threats that can be posed (Ferguson \& Potter, 2004).

The African continent has many countries that are well endowed with deposits of uranium ore where it is mined in 33 countries (Saenz, n.d). These countries include Mali, Algeria, Morocco, Nigeria, Mauritania, Niger, and Somalia. It is therefore imperative that, priority be given to nuclear security though this could be a taxing task due to a number of prevailing security challenges. The African continent is mired with overwhelming challenges which include among others; the increase in the number of SALWs, poverty alleviation and poor service delivery in terms of healthcare and education. Therefore, the implementation of adequate measures of security necessary for diverting non-state actors away from accessing nuclear materials may be a huge challenge.

\section{Material and methods}

A qualitative research design was used for carrying out this review. The research method of a documentary analysis was mainly utilised for reviewing extant literature on the presence of Al-Qaeda in Africa and the security threats posed. Document analysis has been described by Hefferman (2013) as analysing data by examining documents collected from secondary sources such as research reports, textbooks, newspapers and datasets which are related to a given study. It includes extensive reading of text data in order to understand deeply the area under study. Data analysis was inductively done with conclusions made through reasoning. The interpretive paradigm seeks to unearth and decode the concealed meanings for the public's consumption (Adom, Yeboah \& Ankrah,2016). This interpretation was used to develop policy recommendations of $\mathrm{Al}$ Qaeda's current presence and threats to security.

\section{Results and discussion}

\section{Findings and discussion}

Beginning of 2007, the US made its intention to establish a one combatant African command which would combine the entire programmes of security which is supported. This is what became popularly known as the AFRICOM which was expected to operate at full throttle by end of 2008. Prior to this development, the defence operations by the US in Africa were apportioned to the European Union Command (EUCOM), which spanned Central, Southern and West Africa. The Central Command extended over to the Horn of Africa while the Pacific Command extended into the island base situated at Diego
Garcia as well as marine programs associated with the Middle East. This idea of creating a unified African command appears to be noble in providing more focused and harmonised programmes of security to the continent (Lyman,2017).

But, the pronouncement of setting up a command prompted questions raised concerning the US security plans in Africa. The US increased efforts of countering terrorism and that of oil production security heralds, to some, a robust emphasis on security by the US-Africa policy ((Lubeck, Watts \& Lipschutz, 2007). Those critics believe that such concerns could 
overshadow the primacies of fostering justice, democracy, human rights and economic development. For others, this could culminate in the consolidation of African security forces (AlPessin,2007; Mills \& Herbst, 2007).

Such a controversy became more elaborate at the outset when the US was not able to lay bare the mission of AFRICOM. The earlier explanations focusing on organisational processes and the interest to coordinate future and current programmes was more muddled than clear (CFR,2007). It came to be known later that, AFRICOM was not going to serve as a clone of commands that traditionally existed but an institution with a focus to build capabilities for Africans to govern effectively (Cohen, 2007).

However, in light of the fact that, problems in Africa are more to do with poverty than security, African non-governmental organisations and some US Agency for International Development (USAID) remain apprehensive that their efforts for developmental activities could gradually be implanted in the US intelligence and security matters, like what transpired in Afghanistan and Iraq. Also, some politicians in Africa scored political points against the US by loudly and clearly opposing the mooted idea of AFRICOM. These included the South African and Nigerian governments (Hartley,2007). After wide consultations in the African countries AFRICOM had to be where EUCOM is based in Stuttgart, Germany.

For Africa, judging from President Trump's overt disinterest in it, a reduced US military participation could have been anticipated. Instead, at first, his administration augmented operational resources, particularly in Niger and Somalia. The strategy seemed to be focused on reducing peacekeeping and foreign aid while escalating the war on ISIS and AI Qaeda in Africa. Such a policy is informed by previous US administrations although in 2017 the intensification of the war against terrorism on the continent was something new.

In abandoning the limited approach by those who came before him, the Trump administration removed the AFRICOM statement of assuming the continual approach of providing limited resources as the US objective (AFRICOM,2017). Perhaps, Trumps' idea could have been an increased presence of the US in Africa and continue a global fight against ISIS and Al Qaeda. This appears to resonate with his strategy of significantly using security power to triumph over terrorism (Brechenmeier \& Feldstein, 2017). In early August 2018 the US announced plans to significantly reduce its forces in Africa. This reduction will not affect Somalia as it will be done in the West and Central Africa (Vandiver, 2018). The withdrawal, though partial is meant to give more attention ostensibly to a greater competition of power by what the administration views as a military peers' competitors with China and Russia (Rempfer,2018). It could also be that the deadliest groups of terrorists posing more serious threats to the US in Central and West Africa have been devastated. This observation is explained by the non-withdraw of troops at war with Al-Shabaab which is one of the US major threat.

In sum, indications show a burgeoning possibility for Al Qaeda to significantly establish a degree of presence and influence in Africa. Under the circumstances, this is a matter for concern, especially when most countries have very limited resources and competencies to face a threat of that magnitude. More so without substantial help from superpowers like the US and its allies. Undoubtedly, there are many among the marginalised and disenfranchised Africans yearning to revenge against some other people for perceived or real injustices, as well as desirous to redress a political and socioeconomic imbalance. Spin doctors from AlQaeda can easily exploit such vulnerable people by pledging to empower and emancipate them through righting the wrong. Jihadists may additionally highlight the various push factors to justify their cause for violent terrorism in a bid to garner support.

Nevertheless, in order to genuinely appreciate the scope and nature of the purported security threat, it is only prudent to balance these insinuations by identifying the challenges faced by Al-Qaeda in an attempt to advance its influence on the continent. There 
are indeed very significant and real constraints which the network of this extremist group encounters. These challenges could help to apprise a more robust and extensive effort for counteracting the group's attempts to extend its influence or expand its presence in Africa. In reality, Africa presents comparatively very few innuendoes of an environment which is hospitable and tolerant of Al-Qaeda's ideological disposition to resonate with. As opposed to Central Asia and the Middle East, historically Africa has no extremist Salafi Islamism. In many cases, it is the strength of the less extreme Sufi Islamic conventions and practices that have barricaded efforts by the Salafi or Wahhabi clerics from proselytising in order to put influence on the African continent.

Security threats and US policy implications

In view of Al Qaeda's security threats revealed in this study, the US could undertake a number of moves which include leading the diplomatic efforts in Libya. It is clear that, the unrest obtaining in Libya is instrumental to terrorism in the Sahel region especially in Mali and in North Africa. Although it may not be easy for several states to help restore the country's stability, the US appears to be the sole country at the moment wielding sufficient power and diplomatic weight for the desired intervention.

- It is compelling that accountability is demanded from other partners working on the war on terrorism. For instance, the US had to suspend its support to the Somali National Army in 2017 after realising that some of the resources provided as assistance was being stolen. Yet, it is evident that terrorist organisations thrive on food, weapons and money not accounted for. Such theft and corruption stand as a good recipe for instability.

- There is a need to pile pressure and dissuade countries from exporting extremist philosophies. For instance, for many years, Saudi Arabia has been in the habit of exporting Wahhabism which is a dangerous Salafism component. Salafism itself is the Islam practice to which ISIS and AI Qaeda groups subscribe.

- Saudi Arabia must be pressured to immediately stop any further Salafism export, and to undertake the arduous work of reversing the proselytising of Salafism damage that has been done already in some parts of Africa and worldwide.

- That said, it is also incumbent upon the US administration to be aware of challenges that Turkey can employ through its rising prominence in Africa to export its form of Islamism.

- The US has to devise means of operating with affected countries by creating integration strategies in the management of fighters returning from foreign lands. Currently, lots of fighters for ISIS are held in the North of Syria but are likely to be sent back to their countries of origin and this includes countries in Africa. Such countries have no potential to rehabilitate or prosecute them accordingly.

- In an attempt to reduce poverty in Africa, the US could re-orient its focus on programmes of humanitarian aid towards free-market solutions. These solutions are approaches proven for poverty reduction, noting that one of the major contributory factors to a thriving terrorism environment is poverty.

\section{Conclusions}

On the whole, the presence of Al-Qaeda in Africa has been known to be very robust in a few Eastern and Northern countries, and not very strong in the Southern, Central and Western parts of the continent. Beyond Al Qaeda's wellknown activities in Africa, several sources of information exist where one finds affirmations and indicators for anecdotes of a deeper and broader Al-Qaeda security threat to Africa. But much of it is centred on how the conditions in the localities create a conducive environment that resonates with the ideology of Al-Qaeda.

The African continent is susceptible to the whims of war on terrorism globally. Terrorist networks that are sponsored internationally have been able to strike targets in the US and Israel from Africa. They have created cells locally that could possibly strike in Africa as well or 
conscript fighters to operate somewhere else. There are elements appropriately sympathetic among the populations who can ably provide terrorists with safe haven as they flee from America or Europe. It is noted that, sub-Saharan Africa is far less internationally integrated into extreme Islamic terrorism than North Africa. Moroccans and Algerians have participated in various acts of terrorism in Europe and represent a big number of people from Africa who have travelled allegedly all the way to Iraq and join Al-Qaeda guerrillas. Sub-Saharan Africa does not have immunity to terrorism because, terrorists look for and are more successful in states that are weak as opposed to failed states. They thrive by tapping into a state's weaknesses in terms of security, intelligence capacity and the poverty of those elements who are disgruntled or marginalise. Weak states are replete on the African continent.

Therefore, Africa's challenge in fighting terrorism is one of balancing a genuine tight security programme while promoting good governance, alleviating poverty, and improving human rights. It is very necessary to have these issues balanced because African democracies are in a fragile state. Otherwise, any meaningful terrorist crackdown should be done with a great understanding of the historical causes of distress for the marginalised people. This explains why the US programmes of counter-terrorism should not only be predicated on the apparatus of security, in spite of AFRICOM's broad and good approach.

The US administration needs to revisit these concerns in its efforts for counterterrorism. The good thing for the US is that it appears that African countries are in agreement over the war on terrorism and hence they are ready to collaborate with the US for their own security and safety despite their limitations due to other priorities. The US policy recommendations highlighted in this study if implemented, could go a long way to improve security threats in Africa owing to the presence of Al Qaeda and other terrorist groups. The current tools used broadly for responding to terrorism such as the Millennium Challenge Account and the increase in aid by the US are commendable. Having all these in place, a sustained engagement, AFRICOM, together with Africa in partnership in this area of security, more can be achieved for a mutual benefit.

\section{References}

Adesoji, A. (2010). The Boko Haram Uprising and Islamic Revivalism in Nigeria. Africa Spectrum, 45(2), 95-108.

Adom, D., Yeboah, A., \& Ankrah, A. K. ()ctober 2016). Constructivism Philosophical Paradigm : Implications for Reasearch, Teaching and Learning. Global Journal of Arts Humanities and Social Sciences, 4(10), 1-9.

AFRICOM. (2017, March 9). United States Africa Command 2017 Posture Statement. Retrieved February 10, 2020, Available from: http://www.africom.mil/mediaroom/document/28720/africom-2017posture-satement

AFRICOM. (2018, May 2). United States Africa Command Posture Statement. Retrieved January 25, 2020, Available from: http://www.africom.mil/mediaroom/document/30467/u-s-africacommand-posture-statement
Agbiboa, D. (2014). Terrorism Without Borders: Somalia's Al-Shabaab and the Global Jihad Network. Journal of Terrorism Research, 5(1), 29-31.

Al-Hayat. (2010, August 20). A Deal Reached with Al-Qa'idah in the Arab Maghreb.

Al-Pessin. (2007, April 23). African Officials Express Concern About U.S Africa Command Plan. Retrieved February 12, 2020, Available from: http://www.globalsecurity.org/military/library /news/2007/04/mil-0704

al-Shishani, M. B. (2010). Salafi-Jihadis in Mauritania at the Center of Al-Qaeda's Strategy. Terrorism Monitor.

AMM. (2010, October 2). Boko Haram Releases Eid Al-Fitr Address Via Al-Qaeda in North Africa's Media Division Calling on Muslims to Wage Jihad. Arabic Media Monitor.

Baldauf, S. (2009, December 27). Al Qaida Rises in West Africa. Retrieved January 11, 2020, 
Available from Christian Science Monitor: http://www.csmonitor.com/World/Africa/200 9/1228/Al Qaida-rises-in-West-Africa

Bergen, P. (2002). Holy War. New York: Free Press.

Boettcher, M., \& Arnesen, I. (2002, January 24). Al Qaeda Documents Outline Serious Weapons Program. Retrieved from CNN: http://edition.cnn.com/2002/US/01/24/inv.al. qaeda.documents/index.html?_s=PM:US

Brechenmeier, S., \& Feldstein, S. (2017, October 18). Trump's War on Terror. Retrieved February 10, 2020, Available from National Interest: https://nationalinterest.org/feature/trumpswar-terror-22783

Burke, J. (2004). Al-Qaida. London: I.B. Taurus. Byman, D. (2010, December 7). Al Qaeda's M \& A Strategy. Retrieved February 10, 2020, Available from Brookings Institution: https://www.brookings.edu/opinions/alqaedas-ma-strategy

Callimachi, R., Cooper, H., Schmitt, E., Binder, A., \& Gibbons-Neff, T. (2018, February 20). An Endless War: Why 4 US Soldiers Died in a Remote African Desert. Retrieved February 3, 2020, Available from New York Times: https://www.nytimes.com/interactive/2018 /02/17/world/africa/niger-ambushamerican-soldiers

CFR. (2007, April 11). "The Pentagon's New Africa Command" meeting with Admiral Robert Moeller and Ambassador Robert Loftus. Retrieved January 18, 2020, Available from Council on Foreign Relations: http://www.cfr.org/publications/13348/25k

Cohen, H. (March-April 2007). The U.S. Military's New Africa Command. Peace Operations 2, no. 5.

CTC-Report. (n.d). Al Qaida's Misadventures in the Horn of Africa. Retrieved February 13, 2020, Available from Combating Terrorism Center: http://ctc.usma.edu

Daly, J. (2005, March 24). Libya and Al-Qaeda: A Complex Relationship. Terrorism Monitor.

DS. (2005, April 30). Chapter 8; Other Groups of Concern. Country Reports on Terrorism. US Department of State.
FBI. (2011, June). Executive Summary of FBI's Investigation into the Embassy Bombings. Retrieved January 12, 2020, Available from: http://www.pbs.org/wgbh/pages/frontline/s hows/binladen/bombings/summary.html

Ferguson, C. D., \& Potter, W. C. (2004). The Four Faces of Nuclear Terrorism. Monterey, CA: The Center for Nonproliferation Studies, Monterey Institute of International Studies.

Forest, J. (September 2011). Al-Qaeda's Influence in Sub-Saharan Africa Myths, Realities and Possibilities. Perspectives on Terrorism, 5 (3 Special Double Issue on Terrorism and Political Violence in Africa), 6380. Retrieved February 24, 2020, from https://www.jstor.org/stable/26298524

GPO. (2004). The 9/11 Commission Report. Washington, DC: Government Printing Office. Griffin, C. (2018). Trump and the Al Qaeda and ISIS Networks in Africa. RENNES PUR, XVI(2). DOI: $10.4000 /$ lisa. 10157

Hamlin, B. T. (2005, March 10). International Relations Committee Subcommittee on International Terrorism and NonProliferation. New York: European Plans and Operations Center United States European Command.

Hartley, W. ( 30 August 2007). More U.S. Soldiers Not Welcome in Africa, Says Lekota. Johannesburg: Business Day .

Hefferman, C. (2013). Qualitative Research Approach. Retrieved February 4, 2020, from www.explorable.com

Holt, A. (1 December, 2004). South Africa in the War on Terror. Terrorism Monitor.

Jeanne, S. (2013, May 21). "Next Generation Cooperation Threat Reduction Act of 2013". Statement for the Record. Retrieved March 10, 2020, from Institute for Science and International Security. Homeland Security Digital Library.: www.hsdl.org.lib.utep.edu/ ?view\&did=738009

Joscelyn, T. (2017, February 18). Osama bin Laden's Files: AQIM Commander Recommended Training Boko Haram Members. Retrieved February 10, 2020, Available from Long War Journal: https://www.longwarjournal.org/archives/2 
017/02/osama-bin-ladens-files-aqim-leaderrecommended training-boko-haramsmembers.php

Kandel, M. (2014, December 17). La stratégie américaine en Afrique: les risques et contradictions du Light Footprint. La Stratégie américaine en Afrique, Etudes de I'IRSEM n ${ }^{\circ} 36$.

Kandel, M. (2016, Novermber 18). Pour l'armée américaine, l'Afrique est un laboratoire de la lutte antiterroriste. Retrieved February 11, 2020, Available from Le Monde: https://www.lemonde.fr/international/articl e/2016/11/18/maya-kandel-pour-l-armeeamericaine-l-afrique-est-un-laboratoire-dela-lutte-antiterroriste_5033345_3210.html

Kennedy-Boudali, L. (2009, November 17). Examining U.S. Counterterrorism Priorities and Strategy Across Africa's Sahel Region. Testimony Presented Before the Senate Foreign Relations Committee, Subcommittee on African Affairs on 17 November. Santa Monica: RAND Corporation.

Krech, H. (2011). The Growing Influence of AlQaeda on the African Continent. Africa Spectrum, 46(2), 125-137.

Lubeck, P., Watts, M. J., \& Lipschutz, R. (2007, February). Convergent Interests: U.S. Energy Security and the 'Securing' of Nigerian Democracy. Retrieved January 18, 2020, Available from Center for International Policy: http://www.ciponline.org

Lumpkin, J. J. (2002, January 30). Diagrams Show Interest in Nuke Plants. Retrieved January 5, 2020, Available from Associated Press,: http://www.mrt.com/import/article_534555 2b-a052-5324-956f-

56da861e6a34.html?TNNoMobile

Lyman, P. (2017). The War on Terrorism in Africa. In J. Haberson (Ed.), Africa in World Politics (6th ed., pp. 1-361). New York: Routledge.

McCloud, K., \& Osborne, M. (2001, November 20). WMD Terrorism and Usama Bin Laden. Retrieved January 11 Report, 2020, Available from

CNS: http://cns.miis.edu/pubs/reports/binladen.ht m
McConnell, M. (2008, February 5). Annual Threat Assessment of the Director of National Intelligece for the Senate Select Committee on Intelligence. Retrieved March 10, 2020, Available from: http://www.intelligence.senate.gov/080205 /mcconnell.pdf

Memier, M. (2017, janvier). AQMI et AlMourabitoun: le djihad sahélien, réunifié ? Etudes de l'Ifri.

Meservey, J. (2019, December). The Current Terrorism Landscape in Africa. Congressional Testimony: Testimony before the Subcommittee on National Security Committee on Oversight and Reform United States House of Representatives. Washington DC: Office of Government Information Services (OGIS). Retrieved January 29, 2020, Available from: https://www.archives.gov/ogis/aboutogis/congressional-testimony

Mills, G., \& Herbst, J. (2007, April). Africa, Terrorism, and AFRICOM. Retrieved February 12, 2020, Available from RUSI Journal: http://www.rusi.org

Mowatt-Larssen, R. (2010, January 10). Al Qaeda's Pursuit of Weapons of Mass Destruction. Retrieved January 4, 2020, Available from Foreign Policy: http://www.foreignpolicy.com/articles/2010 /01/25/al_qaedas_pursuit_of_weapons_of_ mass_destruction

Nasiri, O. (2006). Inside the Jihad. New York: Basic Books.

Paquette, D., \& Warrick, J. (2020, February 23). Isis and al-Qaeda Join Forces in West Africa. Retrieved February 24, 2020, Available from The Washington Post: https//www.hstoday.us-isi-and-al qaeda Rempfer, K. (2018, August 2). Report: AFRICOM looks to cut special ops missions, pull out hundreds of troops from Africa. Retrieved February 10, 2020, Available from Military Times:

https://www.militarytimes.com/news/your military/2018/08/02/report-africom-looksto-cut-special-ops-missions-pull-outhundreds-oftroops-from-africa/, 
Saenz, L. (n.d). WMD Terrorism and the Al Qaeda Network : An Analysis of AQIM and Al Shabaab. Retrieved March 10, 2020, Available from https://www.utep.edu/liberalarts/nssi/_File s/docs/Capstone\%20projects1/Lisa-SaenzCapstone.pdf

Schanzer, J. (2007, May 28). Pretoria Unguarded: Terrorists Take Refuge in South Africa. Weekly Standard, Vol. 12, No. 35.

Schroeder, M. (2011). Holy Grails: Libya Loses Control of its MANPADS. Jane's Intelligence Review, 5, 18-22.

Schwartz, S. (2010, May 4). Is Nigeria a Hotbed of Islamic Extremism. USIP Peace Brief 27. Washington, DC: U.S.: Institute of Peace.

Searcey, D., Cooper, H., \& Schmitt, E. (2017, October 20). Conflicting Accounts in Niger Ambush are Subject of Pentagon Investigation. Retrieved January 16, 2020, Available from New York Times: https://www.nytimes.com/2017/10/20/worl d/africa/niger-ambush-conflictingaccounts.html

Shillinger, K. (2006, February). Al-Qaida in Southern Africa. Retrieved January 18, 2020, Available from Armed Forces Journal: http://www.armedforcesjournal.com/2006/ 02/1813653/

Stenersen, A. (2017). Al-Qaida in Afghanistan. Cambridge: Cambridge University Press.
Thomas, C. (2018, February 5). Al Qaeda and US Policy: Middle East and Africa. Congressional Research Service CRS Report R43756.

Trump, D. (2017, October 25). Remarks in an Exchange with Reporters, October 25, 2017. Retrieved February 4, 2020, Available from The American Presidency Project: http://www.presidency.ucsb.edu/ws/?pid=1 28706

Ulph, S. (13 December, 2003). Al Qaida Networks Uncovered in Morocco. Terrorism Focus.

Vandiver, J. (2018, August 2). "Report: General wants to pull hundreds of US troops out of Africa. Retrieved February 10, 2020, Available from Stars \& Stripes: https://www.stripes.com/news/reportgeneral-wants-to-pull-hundreds-of-ustroops-out-of-africa-1.540609

White-House. (2012, June). US Strategy Toward Sub-Saharan Africa. Retrieved February 11, 2020, Available from https://20092017.state.gov/documents/organization/20 9377.pdf

Wright, L. (2006). The Looming Tower. New York: Knopf.

Zaitseva, L., \& Hand, K. (2003). Nuclear Smuggling Chains: Suppliers, Intermediaries, and End-Users. American Behavioral Scientist, 822(46), 822-844. DOI: $10.1177 / 0002764202239177$ 